\title{
Implementasi Pengembangan Pojok Wirausaha Mahasiswa Berbasis Online Web Marketing Di Universitas Muhammadiyah Riau
}

\author{
Jusnita $^{1 *}$, Siti Samsiah ${ }^{2}$, Asrinda Amalia ${ }^{3}$, Edo Aribe ${ }^{4}$ \\ ${ }^{1}$ Fakultas Teknik \\ ${ }^{2}$ Fakulta Ekonomi dan Bisnis \\ ${ }^{3}$ Fakultas Ilmu Komunikasi \\ ${ }^{4}$ Fakultas Ilmu Komputer \\ Universitas Muhammadiyah Riau \\ email: jusnita@umri.ac.id
}

\begin{abstract}
The objectives of the Muhammadiyah Riau University (PPK UMRI) Entrepreneurship Development Program are to create new independent entrepreneurs based on web online marketing, increase the network between university entrepreneurship and industrial communities, and create entrepreneurship training methods that are suitable for UMRI students who already have businesses or are just starting out. effort. The approach method used in this activity is entrepreneurship and business training, entrepreneurship coaching, internships at partner companies, building networks and partnerships with partner companies, production and marketing management training, webbased online marketing business meetings and business consultations with guidance, supervision of tenants, tenant business financing techniques, patterns of providing technology assistance and problem solving methods. From this activity, results were obtained in the form of growing interest and motivation for student entrepreneurship, the creation of five new entrepreneurial students in the second year of 2020 who were ready to compete in the community, growing creativity and interest in students to form business entities, building networking between CSR funders and tenants of PPK UMRI students.
\end{abstract}

Keywords: Entrepreneurship Development, Capacity Building, Online web marketing training, Independent Entrepreneurship

\begin{abstract}
Abstrak
Tujuan Program Pengembangan Kewirausahan Universitas Muhammadiyah Riau (PPK UMRI) adalah menciptakan wirausaha baru mandiri yang berbasis web online marketing, meningkat network antara kewirausahan perguruan tinggi dengan masyarakat industri, dan membuat metode pelatihan kewirausahan yang sesuai dengan mahasiswa UMRI yang telah mempunyai usaha atau yang baru merintis usaha. Metode pendekatan yang digunakan dalam kegiatan ini adalah pelatihan kewirausahaan dan bisnis, coaching kewirausahaan, magang pada perusahaan mitra, membangun jaringan dan kerjasama dengan perusahaan mitra, pelatihan manajemen produksi dan pemasaran, business meeting berbasis web online marketing dan konsultasi bisnis dengan pola pembimbingan, pengawasan terhadap tenant, teknik pembiayaan usaha tenant, pola pemberian bantuan teknologi dan metode penyelesaian masalah. Dari kegiatan ini diperoleh hasil berupa tumbuhnya minat dan motivasi entrepreneurship mahasiswa, terciptanya lima entrepreneur baru mahasiswa pada tahun kedua 2020 yang siap berkompetisi di tengah masyarakat, tumbuhnya kreativitas dan minat mahasiswa untuk membentuk badan usaha, terbangunnya networking antara penyandang dana CSR dengan tenant mahasiswa PPK UMRI.
\end{abstract}

Kata Kunci : Akuntansi keuangan lembaga, operator keuangan desa, masa pandemik 


\section{PENDAHULUAN}

Tantangan terbesar bagi perguruan tinggi pada saat ini adalah harus mampu menghasilkan luaran (outcome) yang berkualitas tinggi yang bisa bersinerji dengan dunia usaha. Bahkan diharapkan luaran tersebut bisa menciptakan lapangan kerja baru (job creator), baik untuk dirinya sendiri maupun untuk orang lain, sehingga mampu memberikan kontribusi pada penyerapan tenaga kerja dan dapat mengurangi pengangguran. Pada kenyataannya mindset masyarakat Indonesia masih menganggap menjadi pegawai negeri sipil (PNS) merupakan cita-cita dan masih menjadi keinginan sebagian besar dari lulusan perguruan tinggi ketimbang menjadi entrepreneur, maka perlu dilakukan langkah-langkah strategis untuk meningkatkan minat dan jiwa kewirausahaan mahasiswa.

Untuk menumbuhkembang minat dan jiwa kewirausahaan mahasiswa, Program Pengembangan Kewirausahan (PPKUMRI telah membuat model pojok wirausaha mahasiswa yang berbasis online web marketing dan merumuskan kurikulum yang berbasis enterpreneur dimana mahasiswa diwajibkan mengikuti matakuliah kewirausahaan pada semester lima.

Dengan implementasi model pojok wirausaha yang berbasis online web marketing dan rancangan kurikulum berbasis enterpreneur ini yang ikuti oleh proses serta orientasi pembelajaran yang baik dan terintegrasi dengan praktekpraktek usaha mahasiswa di tengah masyarakat, maka diharapkan dapat tercipta unit-unit usaha mahasiswa yang mandiri dan tangguh dari kampus. Pengembangan ini jelas membutuhkan peran dan sinergi dari berbagai pihak. Tidak bisa hanya bertumpu pada salah satu pihak saja.

Seperti dijelaskan Kuntadi (2015) yang menekankan sinergi antara pelaku pengusaha dan stakeholder dalam mendorong pengembangan kewirausahaan untuk keberlanjutan ekonomi nasional. Kemudian, Sulastri dan Dilastri (2015) juga menjelaskan pola interaksi triple helix yang menekankan sinergi tiga kutub yaitu akademisi, bisnis, dan pemerintah. Sinergi ketiga entitas ini memunculkan ruang pengetahuan.

Budiyanto dan Rofieq (2016) mengatakan bahwa IbK merupakan program yang tepat untuk menumbuhkembangkan jiwa wirausaha dan menghasilkan wirausaha baru dari kalangan mahasiswa dan alumni perguruan tinggi. Kaitan dengan itu, dalam rangka meningkatkan usaha tenant/mahasiswa yang telah ada, maka PPK-UMRI melakukan pengembangan wirausaha yang berbasis online web marketing melalui kepercayaan dan dukungan yang diberikan oleh Direktorat Riset dan Pengabdian Kepada Masyarakat Dirjen Kemristekdikti.

Program

Pengembangan Kewirausahan UMRI telah menyiapkan program dan langkah-langkah strategis dalam mewujudkan tujuan program tersebut, untuk mengatasi permasalahan yang dihadapi oleh mahasiswa seperti rendahnya minat, jiwa dan semangat berwirausaha, serta kemampuan dalam berwirausaha yang masih lemah, baik aspek produksi, pemasaran dan pendanaan serta membangun jaringan bisnis. Menurut Thomas W.Zemmerer dalam Dhikrul Hakin (2014), wirausaha adalah orang yang memiliki kemampuan melihat dan menilai kesempatan-kesempatan bisnis, mengumpulkan sumber daya yang dibutuhkan untuk mengambil tindakan yang tepat, mengambil keuntungan serta memiliki sifat, watak dan kemampuan untuk mewujudkan gagasan inovatif ke dalam dunia nyata serta kreatif dalam rangka meraih sukses dan meningkatkan pendapatan.

Program Pengembangan

Kewirausahaan UMRI diharapkan berperan menjadi wadah bagi mahasiswa dalam mengembangkan diri menjadi wirausaha mandiri, membuka peluang 
usaha bagi calon wirausaha baru untuk mendirikan usaha baru dan mampu memberikan solusi serta menjadi wadah bagi tenant untuk bereksperimen dalam bisnis yang dilakoninya. Menurut Kasali (2014), dapat mengantarkan mahasiswa untuk hidup lebih sejahtera, lebih mandiri dan menolong banyak orang dalam mengatasi pengangguran.

Program PPK-UMRI dilaksanakan selama 3 (tiga) tahun berturut-turut, mulai tahun 2019 sampai dengan 2021. Setiap tahunnya dibina sebanyak 20 tenant. Jika pada tahun pertama minimal 5 (lima) kelompok tenant telah menjadi wirausaha mandiri, maka pada tahun kedua direkrut lagi 5 (lima) kelompok tenant yang baru, demikian seterusnya untuk tahun ketiga, sehingga $80 \%$ tenant PPK-UMRI dapat menjadi wirausaha baru yang tumbuh dari kampus.

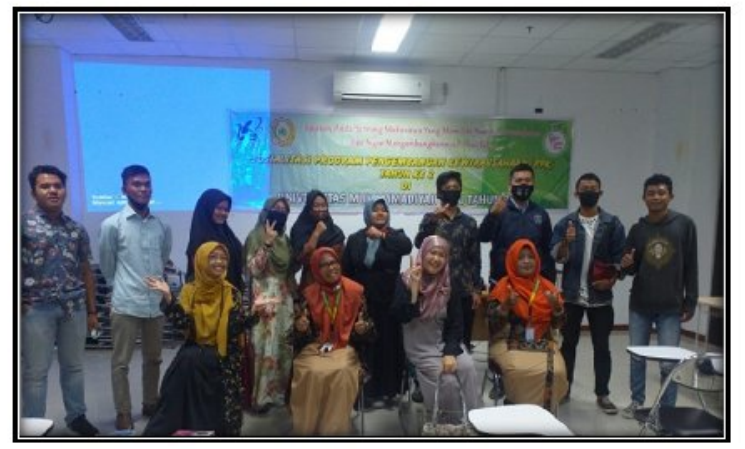

Gambar 1. Peserta Workshop Kewirausahan

Target yang ingin dicapai dari program PPK-UMRI adalah; a) Tumbuhnya minat, semangat dan motivasi Entrepreneurship dari mahasiswa UMRI; b) Terciptanya Entrepreneur baru dari mahasiswa UMRI, minimal 5 orang setiap tahunnya selama 3 tahun berturutturut; c) Tumbuhnya kreativitas dan minat mahasiswa untuk membentuk badan usaha; (4) Terbangunnya net working antara penyandang dana CSR dengan program PPK-UMRI.

\section{METODE PENGABDIAN}

Metode yang digunakan dalam program pengembangan kewirausahaan ini adalah sebagai berikut:

\section{Pola Rekrutmen Tenant peserta PPK}

Program ini dapat diikuti oleh mahasiswa UMRI yang telah menyelesaikan kuliah 5 semester atau yang telah mengambil mata kuliah kewirasuahan.

Mahasiswa yang telah memenuhi syarat diatas akan menempuh seleksi yang meliputi aspek minat, motivasi berwirausaha, kelayakan usaha dan soft skills. Seleksi dilakukan oleh tim profesional dari UPT Kewirausahan dan Pengembangan Karier Universitas Muhammadiyah Riau serta dosen kewirausahan yang ada di lingkungan UMRI. Keterlibatan stakehoders tersebut penting mengingat mahasiswa harus didampingi oleh mentor dari setiap program studi yang terlibat langsung dalam proses pendidikan kewirausahaan yang mempunyai pengalaman praktis berusaha dan perbankan serta berpengalaman dalam hal kelayakan finansial.

\section{Workshop Kewirausahaan}

Metode yang digunakan dalam pelatihan ini melalui tatap muka, dimana narasumber menjelaskan definisi, pengertian, konsep-konsep berwirausaha meliputi teori-teori tentang kewirausahaan, manajemen pengolahan bisnis, strategi pemasaran, manajemen produksi, manajemen keuangan, bisnis plan.

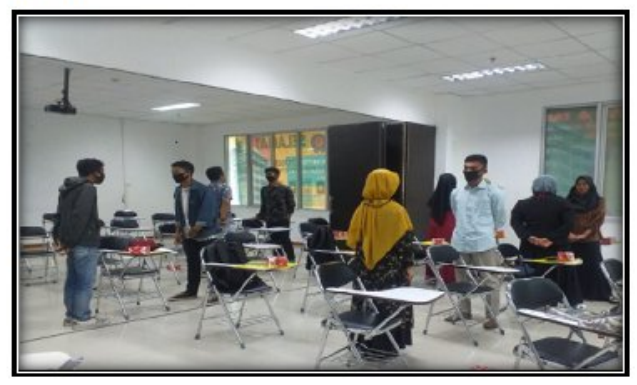

Gambar 2. Diskusi antar peserta

Supaya rekruitment tenant mempunyai tenant yang siap untuk dididik, dilatih dan dibimbing maka perlu diadakan workshop kewirausahan dengan 
tujuan untuk memotivasi tenant dan membentuk mindset tenant menjadi wirausahawan sukses dan mandiri. Workshop kewirausahaan ini terbuka untuk semua mahasiswa, alumni UMRI dan umum. Metode yang digunakan dalam workshop ini adalah penyampaan materi motivasi kewirausahaan (spiritual capital). Dalam diskusi ini tenant didampingi oleh narasumber agar tenant berani mengemukakan pendapatnya dan mendorong untuk berpikir kreatif.

\section{Model Pembelajaran}

Metode pendekatan pendampingan wirausaha di Universitas Muhammadiyah telah disusun secara terstruktur dan berkesinambungan dengan metode Coaching NLP (Neuro Linguistic Program).

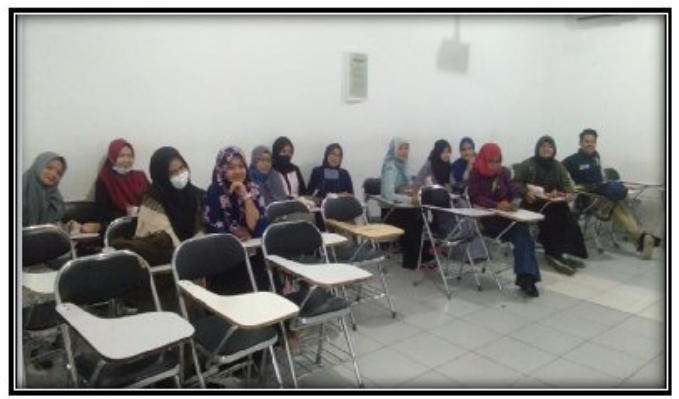

Gambar 3. Coaching Antar Tenant

Pada metode ini akan mengidentifikasi kondisi awal usaha tenant dengan membagi masalah usaha tenant menjadi lima masalah yang lebih spesifik yaitu profil usaha, profil produk, pemasaran, pembukuan dan keuangan. Metode ini dlakukan dengan cara melakukan Focus Group Discussion (FGD) antara tenant, dosen pengampu mata kuliah kewirausahaan dan praktisi serta berupaya menggali kekuatan sumber daya internal dan eksternal masing-masing tenant.

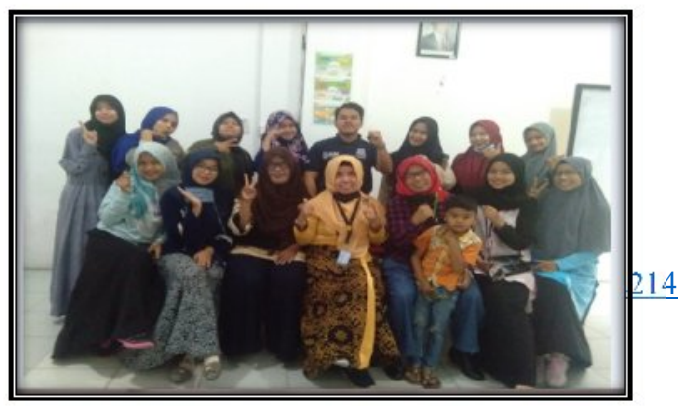

Gambar 4. Focus Group Discussion (FGD)

\section{Metode Magang Pada Industri Mitra}

Metode ini adalah dimana tenant magang pada industri mitra. tenant bekerja sebagai karyawan diperusahaan mitra.

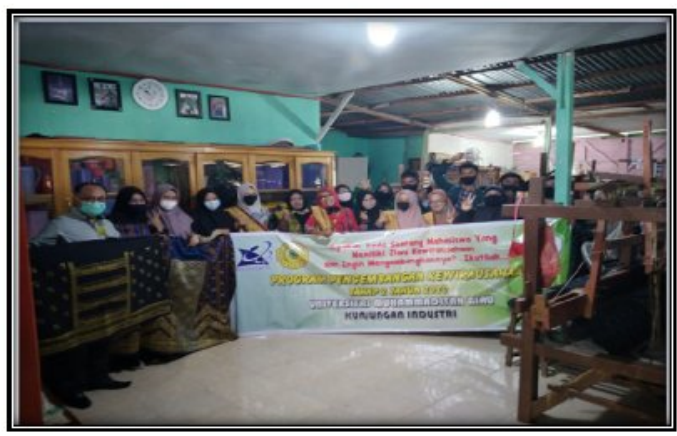

Gambar 5. Tenant Magang

Diharapkan tenant mendapatkan pengalaman tentang proses produksi, baik secara kualitas maupun kuantitas produksi, teknologi yang digunakan dalam proses produksi, membidik pangsa pasar, strategi pemasaran dan kendala-kendala yang dihadapi dalam pengelolaan suatu usaha bisnis dan bagaimana cara penyelesaian masalah. Selesai dari magang, diharapkan tenant memiliki ide-ide kreatif dan inovatif dalam mengembangkan usaha bisnisnya dan dapat membuat Business Plan yang lebih baik dan dapat dipraktekkan sebagai wirausaha mandiri. Pola kegiatan magang ini disebut juga dengan Learning by Doing.

\section{Metode Pembimbingan Terhadap Tenant}

Tenant dibimbing oleh tim pelaksana PPK UMRI yang berpengalaman dibidang kewirausahaan dan mitra usaha. Tenant diberi kesempatan bila ingin konsultasi tentang usaha yang baru dirintis.

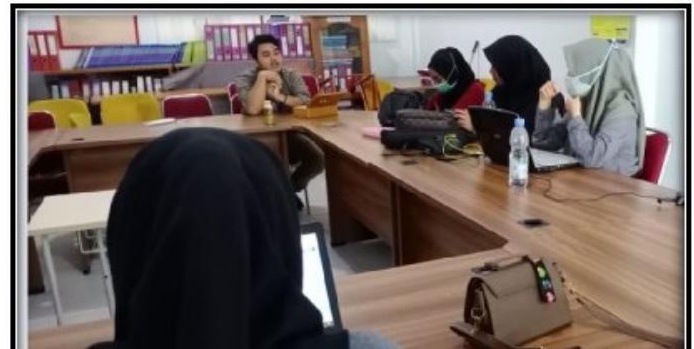


Gambar 6. Pembimbingan Terhadap

Tenant

Tim pelaksana PPK secara aktif terus memotivasi tenant untuk tidak mudah menyerah, apabila menghadapi masalah atau kegagalan, karena kegagalan adalah awal dari sebuah keberhasilan. Bimbingan dan pendampingan dilakukan secara efektif oleh tim pelaksana PPK UMRI setiap minggu dan dilakukan evaluasi terhadap apa yang sudah dilakukan oleh tenant.

\section{Metode Pengawasan Terhadap Tenant}

Tim pelaksana PPK UMRI melakukan pengawasan kepada tenant mulai dari pelatihan, praktek kewirausahaan, magang di perusahaan mitra, pembuatan proposal business plan sampai dengan pengelolaan usaha baru yang dirintis. Pengawasan terhadap tenant diupayakan bersifat edukatif artinya tenant tidak merasa selalu diawasi dan takut bila terjadi kesalahan, tetap diupayakan tim pelaksana bisa membimbing tenant, mengarahkan tenant dan memberikan pembetulan bila terjadi kesalahan

\section{Teknik Pembiayaan Usaha Tenant Dan Bantuan Teknologi}

Setelah tenant berhasil membuat business plan yang baik, maka tenant memulai merintis usaha baru. Pada awalnya tenant membiayai usaha dengan modal sendiri, namun untuk kelangsungan usaha, tenant membutuhkan tambahan dana. Sehingga tim pelaksana PPK UMRI memberikan bantuan teknologi secara bertahap yang diberikan berdasarkan penilaian prospektus usaha tenant. Tim pelaksana PPK UMRI juga ikut mengupayakan untuk mendapatkan CSR dari perusahaan-perusahaan yang dapat disalurkan kepada tenant yang membutuhkan dan juga mengarahkan tenant untuk membuat proposal untuk ikut dalam entrepreneur award LLDikti $\mathrm{x}$ untuk mendapatkan bantuan dana hibah.

\section{Metode Penyelesaian Masalah}

Dalam merintis usaha baru, tentunya banyak menghadapi banyak masalah. Oleh karena itu peran tim pelaksana PPK UMRI sangat dibutuhkan untuk membantu tenant dalam menyelesaikan masalah yang dihadapi tenant.

\section{HASIL DAN PEMBAHASAN}

\section{1) Implementasi Program Pengembangan Kewirausahan}

Implementasi PPK UMRI melalui 3 tahapan, yaitu sebagai berikut;

Sosialisasi dan Seleksi tenant PPKUMRI

Kegiatan sosialisasi merupakan kegiatan awal dari program PPK-UMRI. Komitmen tim PPK-UMRI dalam mencapai tujuan menghasilkan wirausaha muda mandiri telah dimulai sejak awal tahun, yaitu sejak pengumuman pemenang hibah PPK, dimana UMRI sebagai salah satu pemenang hibah tersebut.

Sosialisasi dilakukan dengan metode jemput bola, yaitu tim PPK-UMRI langsung ke dosen kewirausahan dan program studi serta kekelas-kelas memberikan penjelasan kepada mahasiswa, baik yang sudah merintis usaha sendiri maupun yang belum mempunyai usaha, namun mempunyai semangat dan spirit untuk mau berwirausaha. Selain penjelasan langsung, sosialsiasi juga dilakukan dengan membuat pengumuman tertulis tentang penerimaan calon tenant PPKUMRI. Peserta yang berminat kemudian mendaftar diri ketim lewat dosen kewirausahan program studi, yang selanjutnya dilakukan seleksi secara 
tertulis untuk mendapatkan 20 orang mahasiswa yang siap untuk dibimbing dalam PPK-UMRI selama tiga tahun. Dari 20 peserta tersebut diperoleh jenisjenis usaha yang telah dan akan dikembangkan.

Indikator keberhasilan pertama yang dicapai pada program ini adalah banyaknya jumlah pendaftar yang ingin ikut program ini yaitu sebanyak 48 orang. Dari hasil seleksi administrasi dan sesuai dengan kuota hanya yang diterima hanya 20 orang saja untuk tahun kedua 2020 ini. Indikator keberhasilan kedua adalah keseriusan tenant dalam mengikuti program ini ditandai dengan keikutsertaan dalam lomba entrepreneur award IV yang diadakan oleh LLDikti X di kota Jambi.

\section{2) Pelatihan dan coaching PPK}

Pelatihan dan coaching kewirausahaan dan manajemen pembukuan usaha dikuti 20 orang tenant PPK-UMRI. Pelatihan kewirausahaan dan manajemen usaha dilaksanakan selama 3 hari efektif (24 Jam), dengan materi : merumuskan visi dan misi bisnis, motivasi diri (capacity bulding) dan ide bisnis, deskripsi produksi dan teknik penetapan harga pokok dan harga jual, teknik penjualan dan penentuan titik impas, penyusunan business plan, teknik memenangkan persaingan dan menemukan pasar, training pembuatan makanan dari bahan baku kepala ikan menjadi suplemen, training daur ulang limbah serabut sawit menjadi benang, kunjungan industri, pesentasi/ diskusi dan inkubator bisnis.

\section{Pengembangan Model Bisnis Center}

Perencanaan penyusunan dan pengembangan model dilakukan berdasarkan: a). kajian teoritis dan b). fakta empiris di lapangan baik secara konseptual maupun structural. Pertama, kajian teoritis terhadap model Bisnis Center menggunakan analisis SWOT. Hasil analisis SWOT menunjukkan bahwa

Bisnis Center UMRI memiliki kekuatan yang lebih dominan dibanding kelemahannya, dan peluang yang lebih besar dibanding ancamannya.

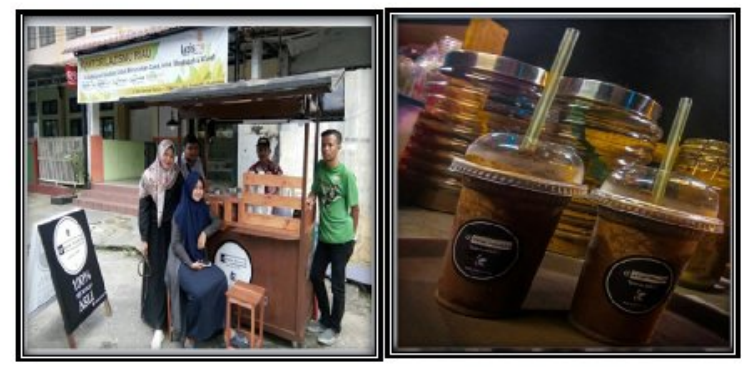

Gambar 6. Tenant dokter coklat

Dengan memperhatikan hasil analisis SWOT, posisi Bisnis Center UMRI berada pada posisi Keadaan Bertumbuh, yaitu memanfaatkan seoptimal mungkin kekuatan memperoleh peluang-peluang yang tersedia di luar lingkungan Bisnis Center UMRI.

Kedua, fakta empiris konseptual menunjukkan bahwa sarana pendukung pelaksanaan Bisnis Center UMRI belum sepenuhnya tersedia, penumbuhan dan penetasan usaha melalui penyediaan fasilitas sarana dan prasarana belum dapat dilakukan dengan baik, struktur dan infrastruktur kurang memadai, administrasi belum dilakukan secara tertib dan rapi, akses jaringan usaha dan informasi serta akses jaringan modal atau pembiayaan di kalangan mahasiswa binaan (tenant) dirasakan masih kurang.

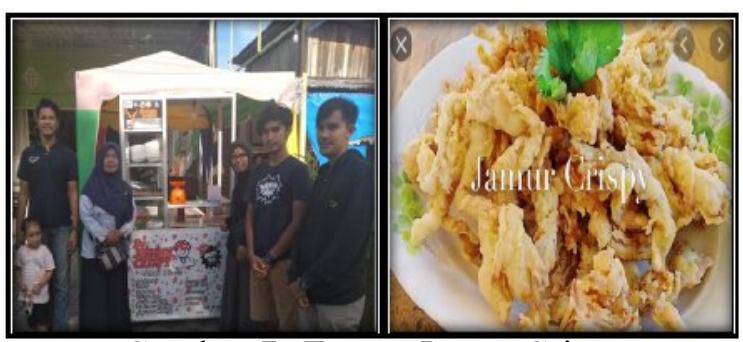

Gambar 7. Tenant Jamur Crispy

Adapun fakta empiris struktural menunjukan bahwa Bisnis Center UMRI sebagai sebuah sistem yang terintegrasi di bawah pengelolaan penrguruan tinggi. Keberadaannya memiliki nilai strategis dalam mengaplikasikan konsep link and 
match. Selain itu, Bisnis Center UMRI berfungsi sebagai wadah bagi pembinaan dan pengembangan kewirausahaan secara akademik yang tetap mengacu pada pengembangan sumberdaya manusia berdasarkan konsep-konsep akademik. Hasil pengabdian kepada masyarakat ini mendukung penelitian Suwandi (2018) yang mengevaluasi model-model Bisnis Center yang dikembangkan oleh perguruan tinggi negeri di Indonesia, yang menyimpulkan bahwa seluruh perguruan tinggi sebelum menentukan model yang akan digunakan terlebih dahulu menyusun berbagai perencanaan model, sehingga dalam pelaksanaan pengembangan model dapat terlaksana dengan baik.

\section{Proses Penyusunan dan Pengembangan Model}

Proses penyusunan dan pengembangan model Bisnis Center di UMRI dapat disimpulkan sebagai berikut: (a). Langkah pertama, melakukan studi pendahuluan untuk mengembangkan pramodel Bisnis Center yang meliputi studi kepustakaan/literature, dan survey lapangan. Berdasarkan kedua hal tersebut dilakukan analisis SWOT dan analisis empiris baik secara konseptual maupun structural. Langkah pertama ini menghasilkan pramodel Bisnis Center; (b). Langkah kedua, melakukan pengembangan model, yang meliputi langkah validasi pramodel yang sudah ada oleh ahli dan pengujian model Bisnis Center, baik skala terbatas maupun skala luas. Berdasarkan langkah-langkah tersebut terwujudlah model Bisnis Center yang telah teruji secara teoritik dan empirik; (c). Langkah ketiga, melakukan uji model dengan membandingkan antara model yang diujicobakan skup terbatas dan model yang diujicobakan dengan skup luas, sehingga tercipta model akhir Bisnis Center UMRI; (d) Langkah keempat, implementasi model sehingga menghasilkan output dan outcome.
Langkah-langkah pengembangan model di atas, pada dasarnya sesuai dengan langkah-langkah pengembangan Bisnis Center yang telah dikembangkan oleh peneliti terdahulu seperti Buchori Alma (2008) dan Ardichvili et.al (2003).

\section{Model Bisnis Center dan implementasi}

Model Bisnis Center UMRI dan implementasi yang akan dikembangkan berorientasi pada inovasi seperti tenant dokter coklat, tenant dokter jamur cripy, tenant original taste drink makyus dan tenant risoles. Sedangkan untuk tenant bisnis plannya adalah limbah kepala ikan teri menjadi suplemen dan limbah serabut sawit menjadi benang.

Prinsip dasar model, sebagai suatu sistem model pelatihan yang berkelanjutan, dalam arti peserta pelatihan tidak hanya lulus pelatihan akan tetapi yang bersangkutan disiapkan untuk menjadi wirausahawan yang handal dan mandiri. Karakteristik model meliputi: a) pelatihan Bisnis Center merupakan kesatuan program pembelajaran bagi mahasiswa, b). sebagai bentuk pelatihan Bisnis Center UMRI yang dibangun atas dasar peluang dan potensi sumberdaya yang dimiliki UMRI, c) pelatihan Bisnis Center dilakukan sesuai dengan minat mahasiswa, d) model ini memerlukan kesediaan pembina, pendamping dan kemitraan usaha dalam menjalankan bisnis baru, dan e). menekankan nilai kejujuran, keuletan, kecerdasan dalam memanfaatkan peluang, mampu melakukan analisis resiko dan berani mencoba menjadi bagian yang tidak terpisahkan dari pengembangan usaha bisnis. Komponen model meliputi: a). masukan input; b). proses Bisnis Center yang terdiri dari teori dan pelatihan; c). output; d). outcome: e). monitoring, evaluasi dan tindak lanjut. Prosedural operasional pelatihan model Bisnis Center UMRI meliputi: a) Menjaring Raw input yaitu mahasiswa semester IV (empat), VI (enam) atau VII (tujuh) yang telah lulus mata kuliah kewirausahaan dan alumni, (b) 
Setelah mendapatkan raw input, maka diberi pelatihan Bisnis Center sebagai bentuk interaksi peserta Bisnis Center, sarana dan sumber belajar untuk melahirkan pengetahuan, keterampilan dan kompetensi kewirausahaan.

Setelah pelatihan teori keterampilan selesai, mereka dikelompokkan dalam unit pengembangan dan inovasi pada Bisnis Center UMRI, (d). Selanjutnya Bisnis Center menghasilkan output yaitu meningkatnya pengetahuan, sikap, keterampilan dan aktivitas peserta Bisnis Center yang aktif dalam kegiatan Bisnis Center yang meliputi; kompetensi inti kewirausahaan, kecakapan, keberhasilan, kerjasama dan mempraktikan hasil pelatihan; (e) Pada tahap akhir dihasilkan outcome yaitu sarjana/alumni sebagai wirausahawan baru yang professional, berwawasan global, mandiri dan inovatif, mampu menciptakan peluang usaha sesuai hasil pelatihan; (f) untuk memantapkan proses Bisnis Center dilakukan monitoring, evaluasi, dan tindak lanjut sebagai alat control terhadap keberhasilan proses Bisnis Center dan upaya perbaikan dan inovasi bisnis sebagai turunan dari Bisnis Center UMRI.

\section{Evaluasi dan Tindak Lanjut, untuk Mengetahui Efektivitas Model.}

Berdasarkan hasil evaluasi dapat disimpulkan bahwa model Bisnis Center UMRI berorientasi inovasi pada kelompok eksperimen dapat dikatakan efektif. Efektivitas pembelajaran tersebut dapat dilihat dari: (a). Tercapainya tujuan pembelajaran sesuai dengan prioritas tujuan yang ditetapkan mahasiswa binaan dengan pengelola Bisnis Center; (b). Memiliki kesesuaian dengan kebutuhan belajar peserta inkubasi; (c). Berpengaruh positif terhadap peningkatan pengetahuan, sikap, perilaku dan keterampilan, sangat mendukung terhadap peningkatan kompetensi kewirausahaan; (d). Dapat menggali, mengoptimalkan dan menyalurkan potensi, bakat dan minat peserta binaan Bisnis Center; (e).
Membantu meningkatkan dan mempercepat proses pembelajaran yang lebih kondusif; (f). Mempunyai dampak yang baik bagi mahasiswa, sehingga mereka memiliki minat untuk menyebarluaskan pengetahuan yang telah dimiliki kepada orang lain, memiliki motivasi, tanggung jawab, kreativitas, inovasi, dan percaya diri yang lebih tinggi.

Tahapan implementasi yang dilakukan terhadap tenant PPK-UMRI adalah sebagai berikut; Tahap pertama adalah pemetaan usaha peserta untuk mengidentifikasi kondisi awal usahanya. Metode yang digunakan adalah chunking, membagi usaha tenant menjadi 5 masalah yang lebih kecil, yaitu keuntungan usaha, produk, pemasaran, pembukan dan keuangan, sehingga lebih mudah dicarikan solusainya. Karena itu dilakukan dengan cara diskusi antara Coach PPK-UMRI dengan tenant. Kemudian menggali sumber daya internal dan eksternal masing- masing tenant.

Tahap kedua, melakukan manuver untuk memperbaiki sikap mental tenant (attitude) dan menemukan teknik-teknik yang dibutuhkan dalam menjalankan kegiatan wirausaha agar lebih efisien dan efektif.

Indikator capaian kegiaan pelatihan dan coaching ini adalah: (a) berubahnya sikap mental tenant untuk mau berbisnis, (b) Tenant mampu menyerap dengan baik materi yang disajikan,(c) Tenant mampu menguasai dan menemukan teknik-teknik yang dibutuhkan untuk menjalankan kegiatan wirausaha agar efisien dan efeektif, misal bagaimana teknik produksi yang baik, bagaimana menghitung harga pokok produk, sistem pemasaran yang baik, bagaimana mengelola keuangan usahanya, dan bagaimana membangun jaringan bisnis yang baik.

3)

4) Pendampingan Usaha Tenant PPK- 


\section{UMRI}

Dalam menjalankan usahanya, tenant mendapatkan pendampingan usaha secara intensif berdasarkan kondisi awal usahanya. Penilaian kondisi awal dilakukan bersama antara tenant sebagai pelaku usaha dengan dosen pendampingnya. Poin yang dinilai terdiri dari 5 komponen pokok, yaitu keuntungan usaha, keuntungan produk/jasa, pemasaran, administrsi keuangan. Berdasarkan kondisi awal tersebut dilakukan manuver untuk memperebaiki sikap mental (attitude) dan menemukan teknik-teknik yang dibutuhkan dalam menjalankan kegiatan wirausaha yang lebih efektif dan efisien, yaitu difusi teknologi, inovasi dan manajeril. Masing-masing tenant mempunyai permasalahan yang berbeda dan spesifik sehingga manuver yang diberikan untuk peningkatan usaha peserta juga berbeda dan spesifik.

Pendampingan usaha bagi tenant dilakukan minimal sekali dalam dua minggu dengan waktu yang telah disepakati antara tenant dan dosen pendampingnya. Setiap bulan dilakukan evaluasi kemajuan usaha dalam bentuk bisnis meeting yang dihadiri oleh semua tenant pelaku usaha dan pendampingnya, dimana setiap peserta memaparkan kemajuan usaha dan kendala-kendala yang dihadapi untuk dicari solusinya.

Sampai pada akhir program 2020, tenant yang telah menjalankan usahanya secara baik adalah sebanyak 10 orang, sedangkan sisanya masih dalam taraf menuju kematangan usaha, dan akan berlanjut pada tahun ke-3 2021.

\section{Strategi Keberlanjutan PPK-UMRI}

Jika PPK-UMRI selama tiga tahun (2019-2021) yang dibiayai oleh DRPM Ditjen Ristekdikti Kemristekdikti ini berakhir, maka program PPK-UMRI bekerjasama dengan UPT Kewirausahan \& Pengembangan Karier ini akan tetap dipertahankan dan berjalan sebagai bisnis center UMRI yang akan menaungi dan membina berbagai aktivitas mahasiswa dalam pengembangan bisnisnya. Agar program PPK-UMRI bisa berkelanjutan, berjalan dan eksis sebagai wadah pencetak wirausaha muda mandiri di Kampus, maka dibutuhkan sumber dana tetap yang bisa membiayai kelangsungan program PPKUMRI.

Strategi yang dilakukan dalam rangka berkelanjutan dan eksis maka unit PPKUMRI kedepan adalah:

a. Menjadikan organisasi PPK-UMRI ini sebagai Inkubator bisnis yang bernaung di bawah UPT Kewirausahan \& Pengembangan Karier UMRI.

b. Menawarkan berbagai jasa dan program Inkubator kepada Koperasi dan UMKM di Riau, baik menyangkut aspek penguatan manajemen usaha, manajemen keuangan, manajemen produksi, akuntansi, penguatan organisasi kelembagaan dan lain-lain.

c. Melakukan pendekatan dengan BUMN di Riau dalam memanfaatkan dana CSR nya, dimana PPK-UMRI berperan dan berfungsi sebagai mediator antara BUMN dengan KUMKM yang membutuhkan pembinaan.

d. Membangun kerjasama dengan tenant alumni yang telah berhasil usahanya untuk membantu mahasiswa yang sedang membangun usahanya di kampus, dengan memberikan shering/bantuan pembinaan lewat PPK-UMRI.

e. Memberikan konsultasi dan bimbinan teknis kepada tenanttenant yang telah berhasil, baik alumni maupun mahasiswa agar bisnisnya tetap berkembang.

f. Melakukan monitoring dan evaluasi secara berkala kepada semua tenant PPK-UMRI, baik yang telah berhasil maupun yang belum, sehingga jika ada kendala yang 
mereka hadapi dapat dicarikan solusinya.

\section{SIMPULAN}

Kesimpulan kegiatan ini adalah: (1) Implementasi program PPK-UMRI tahun 2020 dilakukan melalui tiga tahap, yaitu sosialisasi dan seleksi, pelatihan dan coaching entrepreneurship, manajemen bisnis dan pendampingan; (2) Hasil yang dicapai dari program PPK STIE Nobel Indonesia adalah (a) Tumbuhnya minat dan motivasi Entrepreneurship dari mahasiswa, (b) Terciptanya Entrepreneur baru mahasiswa tahun pertama (2019) sebanyak 5 (lima) orang, (c) Tumbuhnya kreativitas dan minat mahasiswa untuk membentuk badan usaha, (d) terbangunnya networking antara penyandang dana CSR dengan program PPK- UMRI; (3) Jika progam pengembangan PPK-UMRI yang dibiayai oleh DRPM Ditjen Ristekdikti Kemristekdikti berakhir, maka unit PPKUMRI ini akan tetap dipertahankan dan berjalan, yang berfungsi sebagai unit bisnis yang akan menaungi dan membina berbagai aktivitas mahasiswa dalam pengembangan bisnis/wirausahanya. Agar unit PPK-UMRI ini bisa berkelanjutan sebagai wadah pencetak wirausaha muda mandiri, disarankan kepada Universitas Muhammadiyah Riau untuk dapat; (a) dapat menyiapkan dana pendampingan untuk membiayai kelangsungan program PPK-UMRI ini, (b) menjadikan organisasi PPK- UMRI sebagai Inkubator bisnis, menawarkan jasa dan program Inkubator, (c) memberikan konsultasi dan bimbingan teknis kepada tenant binaan, dan melakukan monitoring dan evaluasi secara berkala kepada semua tenant PPK-UMRI

\section{UCAPAN TERIMAKASIH}

Ucapan terima kasih disampaikan kepada DRPM Ditjen Ristekdikti Kemristekdikti yang telah mendanai program ini dari tahun 2019 sampai dengan 2020. Dan ucapan terima kasih kepada LPPM UMRI yang mendukung program PPK ini, serta ucapan terima kasih kepada segenap yang membantu program PPK ini yang tidak bisa disebutkan satu persatu namanya disini.

\section{DAFTAR PUSTAKA}

[1] Harto, D., Pratiwi, S. R., Utomo, M. N., \& Rahmawati, M. (2019). Penerapan

[2] Ragimun, Sudaryanto, \& Wijayanti, R. R. (2015). Strategi Pemberdayaan UMKM Menghadapi Pasar Bebas Asean. Web Kementerian Keuangan, $1-32$.

[3] Saban,Echdar. 2014. Kewirausahaan solusi cerdas atasi pengangguran, Jogyakarta: Depublish.

[4] Dhikrul,Ahkim.2014.Pengembangan pendidikan kewirausahaan berdasarkan nilai-nilai budaya untuk membentuk daya saing dan karier bangsa,Jurnal Kewirausahaan,Vol.1,Juni 2015.

[5] Internet Marketing Dalam Meningkatkan Pendapatan Pada UMKM. Jurnal Pengabdian Dan Pemberdayaan Masyarakat, 3(1), 3945.

[6] Saban,Echdar.2017.Manajemen entrepreneurship- Kiat sukses menjadi wirausaha, Yogyakarta: Andi Ofset 